\title{
Preparation and Properties of Composite Films Composed of Polyimide, Epoxy Resin and Silver Filler
}

\author{
Takashi MASUKO*, Shinji TAKEDA** and Yuji HASEGAWA**
}

ポリイミド／エポキシ樹脂／銀フィラーコンポジットフィルムの調製と特性

増子 崇*, 武田 信司**, 長谷川 雄二**

*日立化成工業株式会社総合研究所実装材料・システム開発センタ（テ300-4247 茨城県つくば市和台 48)

**日立化成工業株式会社総合研究所素材開発センタ（广317-8555＼cjkstart茨城県日立市東4-13-1）

* Laboratory for Electronic Packaging, Materials \& Technology, Research \& Development Center, Hitachi Chemical Co., Ltd. (48 Wadai, Tsukuba-shi, Ibaraki 3004247)

** Laboratory for Advanced Materials, Research \& Development Center, Hitachi Chemical Co., Ltd. (4-13-1 Higashi, Hitachi-shi, Ibaraki 317-8555)

\begin{abstract}
概要 デカメチレンビストリメリテート二無水物(DBTA)を酸成分として合成したポリイミド，エポキシ樹脂，拉よび銀 フィラーからなるコンポジットフィルムを調製し, それらの種々特性を検討した。硬化前においては, Tg を超える温度領域 でメルトダウンし，熱可塑型フィルムに特有の挙動を示したが，硬化後においては，含有するエポキシ樹脂成分の橋かけ化の 効果により，上記の温度領域での流動が抑制された。これらのフィルムを介して，異なる熱ひずみを有する材料同士を貼り合 わせたときの接着強度は，主としてフィルムの弾性率と応力緩和特性の影響を受けることがわかった。本報では、ポリイミド の構造とフィルム特性との関係について詳細に論じた。
\end{abstract}

\begin{abstract}
Composite films composed of various polyimides derived from decamethylene bis(trimellitate)anhydride (DBTA), an epoxy resin and a silver filler were prepared and their properties were studied. The films showed thermoplastic behavior before curing with molten performance at high temperatures above their $\mathrm{Tgs}$, and thermosetting behavior after curing with restricted flow behavior even above their Tgs. The limited flow behavior results from the network structure formation in the film. The adhesion strength of the film when used as an adhesive film between two adherents having different thermal strains was affected by two main factors: the modulus and stress relaxation property of the film. In this paper, the relationship between the chemical structure of the polyimides and the various properties of the composite films is discussed.
\end{abstract}

Key Words: Polyimide, Composite Film, Dynamic Mechanical Properties, Stress Relaxation, Adhesion Behavior

\section{Introduction}

Traditionally, polyimides have been used as materials for application in future aircraft and spacecraft because of their superior thermal, mechanical and electrical properties $^{1)}$. Recently, they have been applied in microelectronic devices as film or varnish for the purpose of miniaturization and improvement in performance and reliability ${ }^{2)}$.

However, most polyimides must be processed in the stage of their soluble poly(amic acid) precursors, which are subsequently imidized by heating at high temperatures over $350^{\circ} \mathrm{C}$. Because they are insolubility and infusibility in their imidization form, polyimides are difficult to process. Furthermore, they must be processed or prepared at high temperatures over $300^{\circ} \mathrm{C}$ due to their high $T g$ or high softening temperature, resulting in the thermal damage of the peripheral materials. Their application fields have been limited for this reason ${ }^{3}$.

In order to obtain soluble polyimides and/or to prepare polyimides at lower temperatures, extensive study has been carried out on the synthesis of polyimides having lower $T g$ or lower softening temperatures by introducting flexible structures such as alkylene, ether, and siloxane connecting groups into the polymer backbone ${ }^{4) \sim 6)}$.

However, these polyimides will only melt down above their $\mathrm{Tg}$ or softening temperatures because of their inherent thermoplasticity. Therefore, it was difficult to develop polyimide-based materials which can be prepared at low temperatures and have high mechanical strength at high temperatures. 
To solve above problem, material design as blending or mixing different polymers and fillers has been studied to develop new materials having various superior properties which cannot be achieved by one component materials $^{77-11)}$. According to such material design, we tried to develop new composite materials, as high performance die attach adhesives for microelectronics applications, having lower fluidity and higher mechanical strength at high temperatures above $T g$, by blending an epoxy resin as a crosslinking agent and a filler as a reinforcement. Extensive study of the mechanical strength of the composite materials will prove that this attempt was a successful approach.

A number of workers have reported the studies on polyimide-epoxy resin composites ${ }^{9)}$ 11). However, the main purpose of these studies was the improvement of the inherent brittleness of the epoxy matrices. Few studies have been reported on the restriction of the flow of polyimide-based composite materials at high temperatures above $T g$ by blending epoxy resins and fillers.

In this study, new composite films composed of a polyimide, an epoxy resin and a silver flake as a filler, which has been filled in silver pastes widely used as current die attach materials, were examined to develop new die attach adhesives which can be attached at lower temperatures and have both good stress relaxation property and high mechanical strength at high temperatures above $T g$. In the previous work ${ }^{12), 13)}$, the effect of con- tents of the epoxy resin and the silver flake on adhesion properties, morphology and rheological properties of the composite films has been demonstrated in detail. In this paper, the composite films using various polyimides were examined and the relationships between the chemical structures of the polyimides and the various properties of the composite films were investigated.

\section{Experimental}

\subsection{Materials}

The structures of the monomers used in this study are shown in Fig. 1. 1,10-(Decamethylene)bis(trimellitate)anhydride (DBTA) and 1,12-(dodecamethylene) bis(trimellitate)anhydride (DDBTA) were used as the dianhydrides $^{14)}$. 2,2'-Bis[4-(4-aminophenoxy)phenyl]propane (BAPP), 4,7,10-trioxatridecane-1,13-diamine (TODE), 4,9-dioxadecane-1,12-diamine (DODE), 1,3-bis(3-aminopropyl)tetramethyl disiloxane (TSX), and bis $(\gamma$-aminopropyl)polydimethyl siloxane (PSX, molecular weight: 914) were used as the diamines. Diglycidyl ether of bisphenol $F$ (DGEBF) and diglycidyl ether of bisphenol AD (DGEBAD) were used as the epoxy compounds (epoxy equivalent weight: 160 and 175, respectively). Phenol novolak resin (PN) was employed as the hardener (OH equivalent weight: 106) and tetraphenylphosphonium tetraphenylborate (TPPK) was used as the curing accelerator. N-Methyl-2-pyrrolidinone (NMP) and xylene were adopted as the solvents for polyimide syn-
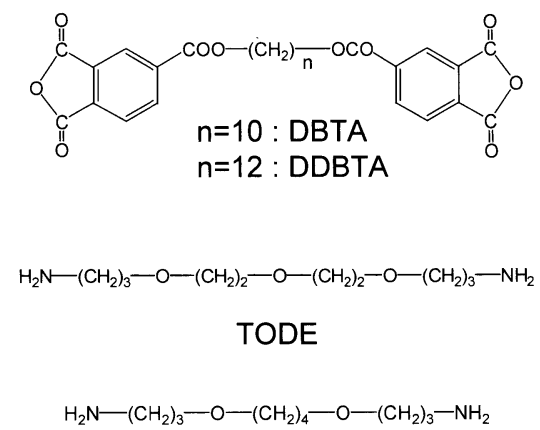

DODE
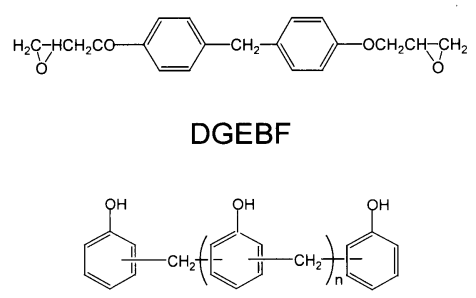

PN
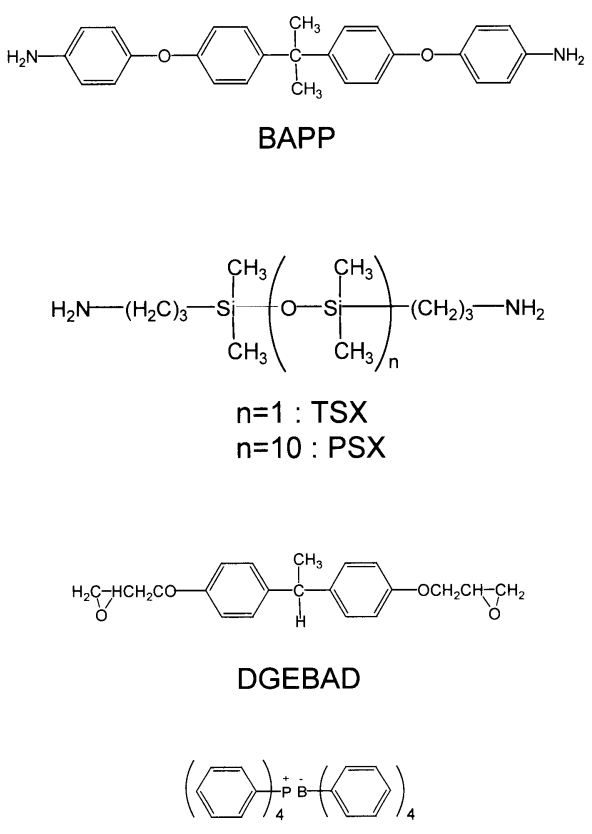

TPPK

Fig. 1 Chemical structures of the monomers 
Table 1. Preparation and characterization of the polyimides

\begin{tabular}{|c|c|c|c|c|c|c|}
\hline \multirow{2}{*}{ Polyimide } & \multicolumn{2}{|c|}{ Monomers [mol\%] } & \multicolumn{3}{|c|}{ Molecular weight distribution } & \multirow{2}{*}{$\operatorname{Tg}\left[{ }^{\circ} \mathrm{C}\right]$} \\
\hline & Dianhydride & Diamine & Mn & $\mathrm{Mw}$ & $\mathrm{Mw} / \mathrm{Mn}$ & \\
\hline PI-1 & DBTA (100) & $\operatorname{BAPP}(100)$ & 32500 & 121000 & 3.73 & 120 \\
\hline PI-2 & DDBTA (100) & $\operatorname{BAPP}(100)$ & 33200 & 102600 & 3.09 & 107 \\
\hline PI-3 & DBTA (100) & BAPP (50)/TODE (50) & 36700 & 115500 & 3.14 & 64 \\
\hline PI-4 & DBTA (100) & BAPP (50)/DODE (50) & 28900 & 88600 & 3.07 & 57 \\
\hline PI-5 & DBTA (100) & BAPP (50)/TSX (50) & 26900 & 80800 & 3.01 & 64 \\
\hline PI-6 & DBTA (100) & BAPP (50)/PSX (50) & 23800 & 68600 & 2.89 & 30 \\
\hline
\end{tabular}

thesis, N,N-dimethylacetamide (DMAc) and cyclohexanone $(\mathrm{CHN})$ were used as the solvents for film preparation. They were highly pure as received and were used without purification except for DBTA and DDBTA, which were used via recrystallization. Silver flake TCG-1 as the filler was obtained from Tokuriki Kagaku Co. (mean size: $2 \mu \mathrm{m}$ ).

\subsection{Synthesis of the Polyimides}

The monomer compositions of the polyimides in this study are summarized in Table 1 . These polyimides were synthesized by a two-step method as shown in Fig. 2 . The polyimide solution was then poured into water. The precipitate polymer powders were collected by filtration, washed with methanol for $6 \mathrm{~h}$, and dried under vacuum at $60^{\circ} \mathrm{C}$ for $12 \mathrm{~h}$, whereby original polyimide powders were obtained. For all the synthesized polyimides (PI-1 to 6), the characteristic absorption bands in the FT-IR spectra ( $\mathrm{KBr}$ ) were observed near 1780 (asym. $\mathrm{C}=\mathrm{O}$ str.), 1720 (sym. $\mathrm{C}=\mathrm{O}$ str.), 1370 (C-N str.), and $720 \mathrm{~cm}^{-1}$ $(\mathrm{C}=\mathrm{O}$ bend $)$, indicating an imide structure. Meanwhile those near $1650 \mathrm{~cm}^{-1}$ due to a poly(amic acid) has disappeared.

\subsection{Preparation of the Composite Films}

The composite films composed of the polyimides (100 parts), the epoxy resin (10 parts, consisting of either DGEBF or DGEBAD, PN, and TPPK), and the silver filler ( $40 \mathrm{wt} \%$ of the total compositions) were prepared as follows: First, polyimide powders, 50/50 wt $\%$ DGEBF/DGEBAD mixture, PN (stoichiometric equivalent of epoxy groups of the epoxy resin and hydroxyl groups of the hardener) and $1 \mathrm{wt} \%$ of TPPK per $100 \%$ of the epoxy compounds were weighed and completely dissolved in 50/50 wt $\%$ DMAc/CHN solvent. Next, the silver filler was added with mechanical stirring. This varnish was casted onto a carrier OPP (biaxially stretched polypropylene) film, followed by heating in an $80^{\circ} \mathrm{C}$ oven for $30 \mathrm{~min}$ and a $120^{\circ} \mathrm{C}$ oven for $75 \mathrm{~min}$ to remove the residual solvents. The resulting composite film

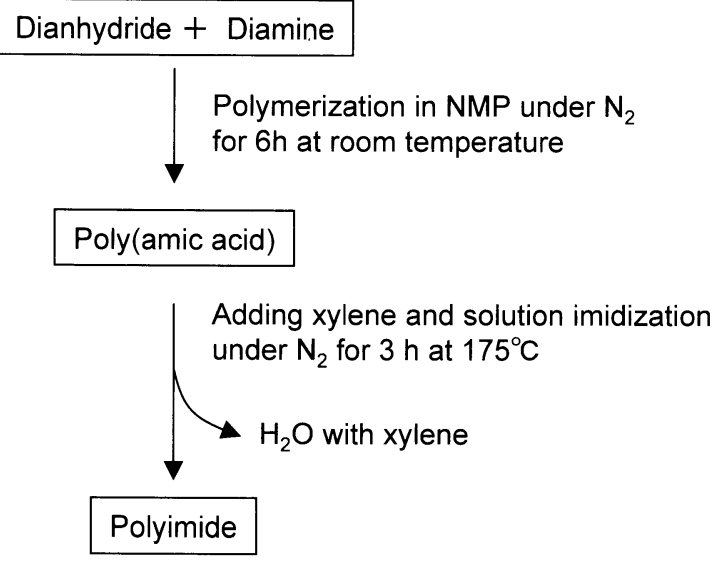

Fig. 2 Synthesis of the polyimide by two-step method

was peeled from the OPP film. Thus, the composite film with $25 \mu \mathrm{m}$ thickness was obtained. Furthermore, to cure the composite film completely, the film was held on an iron frame and heated in a $180^{\circ} \mathrm{C}$ oven for $1 \mathrm{~h}$. The curing condition of the film was determined from the exothermic behavior of the epoxy resin ( $T$ init: 118, $T$ onset: $158, \mathrm{~T}$ exo: 171 , and $\mathrm{T}$ end: $\left.199^{\circ} \mathrm{C}, \mathrm{Tg}: 97^{\circ} \mathrm{C}\right)$ measured with DSC.

\subsection{Measurements}

\subsubsection{Characterizations of the Polyimides}

Molecular weights (number-averaged Mn and weightaveraged $\mathrm{Mw}$ ) and their distributions (polydispersity index: $\mathrm{Mw} / \mathrm{Mn}$ ) of the polyimides were obtained by GPC with a Shimadzu HPLC C-R4A (standard: polystyrene). The $T g$ of the polyimides was obtained by DSC with a Perkin-Elmer DSC-7 at a heating rate of $5^{\circ} \mathrm{C} / \mathrm{min}$ in air. The solubility of the polyimides was evaluated in various solvents (10 wt \% polyimide powders in solvent). The water absorptivities of the polyimides were calculated from the following equation:

$$
\text { Water absorptivity }(\mathrm{wt} \%)=\frac{W_{2}-W_{1}}{W_{1}} \times 100
$$

where $W_{1}$ is the weight of the polyimide film after cured in a $180^{\circ} \mathrm{C}$ oven for $1 \mathrm{~h}$ and dried in a $120^{\circ} \mathrm{C}$ vacuum 
dryer for $3 \mathrm{~h}, W_{2}$ is the weight of the same film after immersed in distilled water for $48 \mathrm{~h}$ at room temperature.

\subsubsection{Properties of the Composite Films}

TGA was carried out in air at a heating rate of $5^{\circ} \mathrm{C} / \mathrm{min}$ using a Shinku Riko TGD-7000. Dynamic mechanical analysis was performed on a solid analyzer RSA-2 from Rheometrics. The dynamic viscoelasticity of the film was measured at a heating rate of $5^{\circ} \mathrm{C} / \mathrm{min}$ and a frequency of $1 \mathrm{~Hz}$. Stress relaxation properties were evaluated as follows: The composite film (size: $5 \mathrm{~mm} \times$ $13 \mathrm{~mm})$ was inserted between a silicon chip $(5 \mathrm{~mm} \times 13$ $\mathrm{mm} \times 400 \mu \mathrm{m}$ thick) and a copper substrate $(16 \mathrm{~mm} \times 20$ $\mathrm{mm} \times 250 \mu \mathrm{m}$ thick) or a silicon chip (15 mm square $\times$ $400 \mu \mathrm{m}$ thick). The samples were compression-bonded under $0.15 \mathrm{MPa}$ at $250^{\circ} \mathrm{C}$ for $5 \mathrm{~s}$, followed by heating in a $180^{\circ} \mathrm{C}$ oven for $1 \mathrm{~h}$ to cure the composite film completely. Silicon chip warpage, which is the index of the stress relaxation property of the composite film, was measured using a surface roughness meter (scan distance: $11 \mathrm{~mm}$ ) as shown in Fig. 3A. The adhesion strength of the composite film was measured as follows: The composite film (size: $5 \mathrm{~mm}$ square) was inserted between a silicon chip ( $5 \mathrm{~mm}$ square $\times 400 \mu \mathrm{m}$ thick) and a silicon chip of a larger size or a copper substrate. The samples were compression-bonded under $0.08 \mathrm{MPa}$ at $250^{\circ} \mathrm{C}$ for $5 \mathrm{~s}$ and cured under the same condition as above. The adhesion strength was measured with a push-pull gauge by peeling the silicon chip at a pulling rate of $0.5 \mathrm{~mm} / \mathrm{s}$ as shown in Fig. 3B. The measurement was carried out at $250^{\circ} \mathrm{C}$ for all specimens (the pulling started $20 \mathrm{~s}$ after the specimen was set on the $250^{\circ} \mathrm{C}$ heater plate).

\section{Results and Discussion}

\subsection{Effect of Monomer Structure on the Charac- teristics of the Polyimides}

\subsubsection{Molecular Weight Distribution and $T g$}

All of the polyimides as-synthesized had $\mathrm{Mn}$ of 23000-36000 and Mw of 68000-121000, and only polyimide PI-6 with polysiloxane diamine PSX had slightly lower Mn and Mw values (Table 1). PSX having longer siloxane units, which will lower the miscibility with NMP during polyimide synthesis due to lowering the polarization of the monomer, may result in the decrease in polymerizability in the solvent.

The $T g$ of PI- 1 measured by DSC was $120^{\circ} \mathrm{C}$, while those of general polyimides such as ULTEM $^{\mathrm{TM}}$ are over $200^{\circ} \mathrm{C}^{15}$. The lower $\mathrm{Tg}$ is due to the introduction of the decamethylene connecting group, a long and flexible
(A)

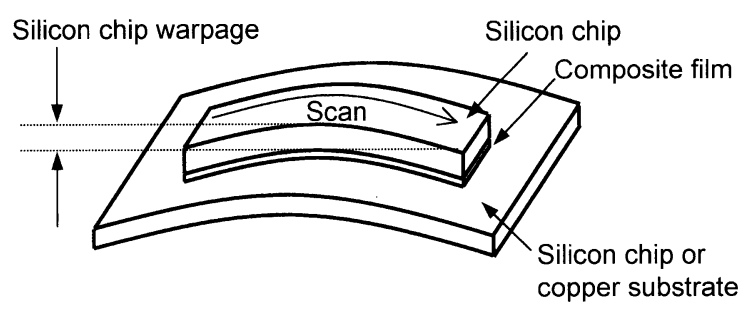

(B)

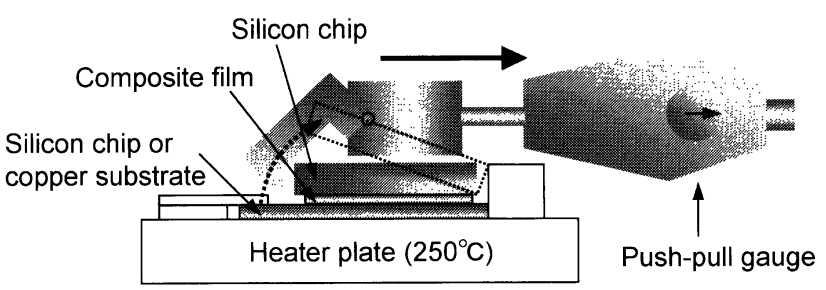

Fig. 3 Measurements of silicon chip warpage (A) and adhesion strength (B)

molecular chain, into the polyimide backbone. Furthermore, the introduction of a dodecamethylene connecting group (PI-2) or several aliphatic ether connecting groups (PI-3 and 4) or siloxane linkages (PI-5 and 6) lowered the $T g$ less than $120^{\circ} \mathrm{C}$. In particular, the introducition of the polysiloxane linkage lowered the $\mathrm{Tg}$ to $30^{\circ} \mathrm{C}$ (PI-6).

\subsubsection{Solubility and Water Absorptivity}

Each polyimide was found to be soluble in polar solvents like NMP, DMAc, CHN, and THF at room temperature (Table 2). However, the solubility for MIBK was different among the polyimides, and each polyimide was sparingly soluble in DMF and insoluble in DMSO. These differences in solubility can be explained by comparing the solubility parameters (SPs) of the solvents with those of the polyimides. According to the solubility theory, a polymer and a solvent having near SP values are miscible with each other ${ }^{16)}$. The SP of the solvents and polyimides were calculated from their chemical structures according to the Okitsu method ${ }^{17)}$. As shown in Table 2, the SP value (11.3) of PI-3 was the highest, and that of PI6 (9.9) was the lowest among the polyimides. The reason for the former is due to that PI-3 contains many ether linkages with relative high polarization, and that for the latter is assigned to that because PI-6 contains polysiloxane linkage with lower cohesive force in the polyimide structure. On the other hand, the SP value of DMF (12.1) was the highest, and that of MIBK (8.4) was the lowest among the solvents. From the relationship between the SP and the solubility of the polyimides, it is found that PI-6 is very easy to soluble in MIBK because the SP values of PI-6 (9.9) and MIBK (8.4) are very near each other. 
Table 2. Solubility ${ }^{\text {a) }}$ and warter absorptivity of the polyimides

\begin{tabular}{|c|c|c|c|c|c|c|c|c|c|}
\hline \multirow[b]{2}{*}{ Polyimide } & \multicolumn{7}{|c|}{ Solvent ${ }^{\mathrm{b})} / \mathrm{SP}^{\mathrm{c})}\left[(\mathrm{MPa})^{1 / 2}\right]$} & \multirow{2}{*}{$\begin{array}{c}\mathrm{SP}^{\mathrm{c})} \\
{\left[(\mathrm{MPa})^{1 / 2}\right]}\end{array}$} & \multirow{2}{*}{$\begin{array}{c}\text { Water absorptivity } \\
{[\mathrm{wt} \%]}\end{array}$} \\
\hline & $\begin{array}{c}\text { MIBK } \\
/ 8.4\end{array}$ & $\begin{array}{c}\text { THF } \\
/ 9.1\end{array}$ & $\begin{array}{c}\mathrm{CHN} \\
/ 9.9\end{array}$ & $\begin{array}{c}\text { DMAc } \\
/ 10.8\end{array}$ & $\begin{array}{l}\text { NMP } \\
/ 11.3\end{array}$ & $\begin{array}{c}\text { DMSO } \\
/ 12.0\end{array}$ & $\begin{array}{l}\text { DMF } \\
/ 12.1\end{array}$ & & \\
\hline PI-1 & \pm & ++ & ++ & ++ & ++ & \pm & + & 10.8 & 0.12 \\
\hline PI-2 & \pm & ++ & ++ & ++ & ++ & \pm & + & 10.6 & 0.10 \\
\hline PI-3 & \pm & ++ & ++ & ++ & ++ & \pm & + & 11.3 & 0.33 \\
\hline $\mathrm{PI}-4$ & \pm & ++ & ++ & ++ & ++ & \pm & + & 11.2 & 0.28 \\
\hline PI-5 & \pm & ++ & ++ & ++ & ++ & \pm & + & 10.9 & 0.10 \\
\hline PI-6 & ++ & ++ & ++ & ++ & ++ & \pm & + & 9.9 & 0.01 \\
\hline
\end{tabular}

a) ++ : soluble at room temperature, + : soluble on heating at $60^{\circ} \mathrm{C}, \pm$; only swelling on heating

b) MIBK: methyl isobuthyl ketone, THF: tetrahydrofuran, CHN: cyclohexanone, DMAc: $N, N$-dimethylacetamide, NMP: $N$-methyl-2-pyrrolidinone,

DMSO: dimethyl sulfoxide, DMF: $N, N$-dimethylformamide

c) solubility parameter

The polyimides having the SP ranging from 9.9 to 11.3 are soluble in the solvents having the SP ranging from 9.1 to 11.3 , and are sparingly soluble or insoluble in the solvents with the SP of 12.0 and over. It is not clear why these polyimides show different solubility between DMSO and DMF, which have almost the same SP values. Polyimides may be more soluble in amide type solvents than sulfoxide type solvents.

The water absorptivities of the polyimides were dependent on their chemical structures (Table 2). Among the polyimides examined, PI-3 containing many hydrophilic ether linkages had the highest water absorptivity, and PI-6 containing hydrophobic polysiloxane linkage had the lowest one. As a result, a close correlation between the SP and the water absorptivities of the polyimides was found. That is, the increased SP of a polyimide towards the SP of water (23.4), results in the increased water absorptivity of the polyimide.

\subsection{Preparation and Properties of the Composite Film Based on PI-1}

\subsubsection{Thermal Property}

The weight loss behavior of PI-1 film and PI-1/epoxy resin blend film (both cured at $180^{\circ} \mathrm{C}$ for $1 \mathrm{~h}$ ) was evaluated by TGA in air and is shown in Fig. 4A. The former film was $20^{\circ} \mathrm{C}$ higher than the latter film at $5 \%$ weight loss temperature $\left(378\right.$ and $\left.358^{\circ} \mathrm{C}\right)$. However, its weight loss at over $400^{\circ} \mathrm{C}$ was higher than the latter. The oxidative degradation of PI-1 will occur at over $400^{\circ} \mathrm{C}$. The blend of the epoxy resin into the polyimide results in reducing the weight loss of the film at these temperatures. This result suggests that the compatible behavior of the polyimide/epoxy resin blend is a chemical blend such as semi-interpenetrating polymer network (semi-IPN) ${ }^{18)}$ with some chemical reactions each other.

The weight loss behavior of the composite film of PI-
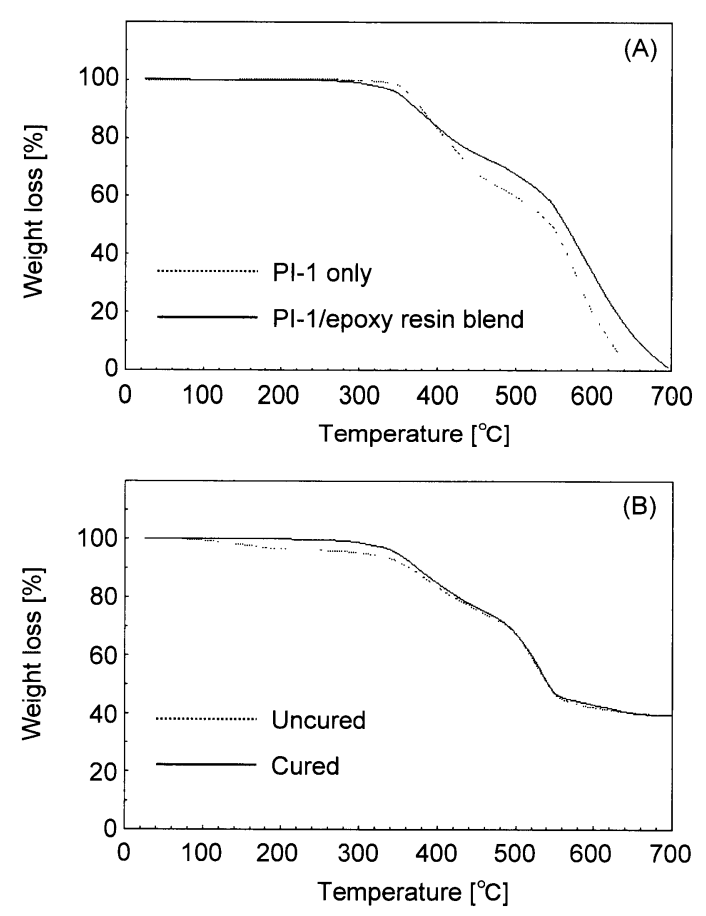

Fig. 4 TG thermograms of PI-1 and PI-1/epoxy blend films (A) and the composite film of PI-1/epoxy resin/silver filler (B)

1/epoxy resin/silver filler is shown in Fig. 4B. The uncured film showed $5 \%$ weight loss at about $120^{\circ} \mathrm{C}$. This weight loss is due to the volatilization of the residual solvents in the film. On the other hand, that of the cured film was $358^{\circ} \mathrm{C}$. This temperature agreed with that of the base resin (PI-1/epoxy resin blend) shown in Fig. 4A. The result indicates that the thermal degradation behavior of the composite film depends on the property of the base resin, and the silver filler does not affect the degradation of the composite film.

\subsubsection{Dynamic Mechanical Properties}

The effect of curing on the dynamic mechanical properties of the composite film is shown in Fig. 5. A clear difference in the storage modulus $\left(E^{\prime}\right)$ was observed be- 

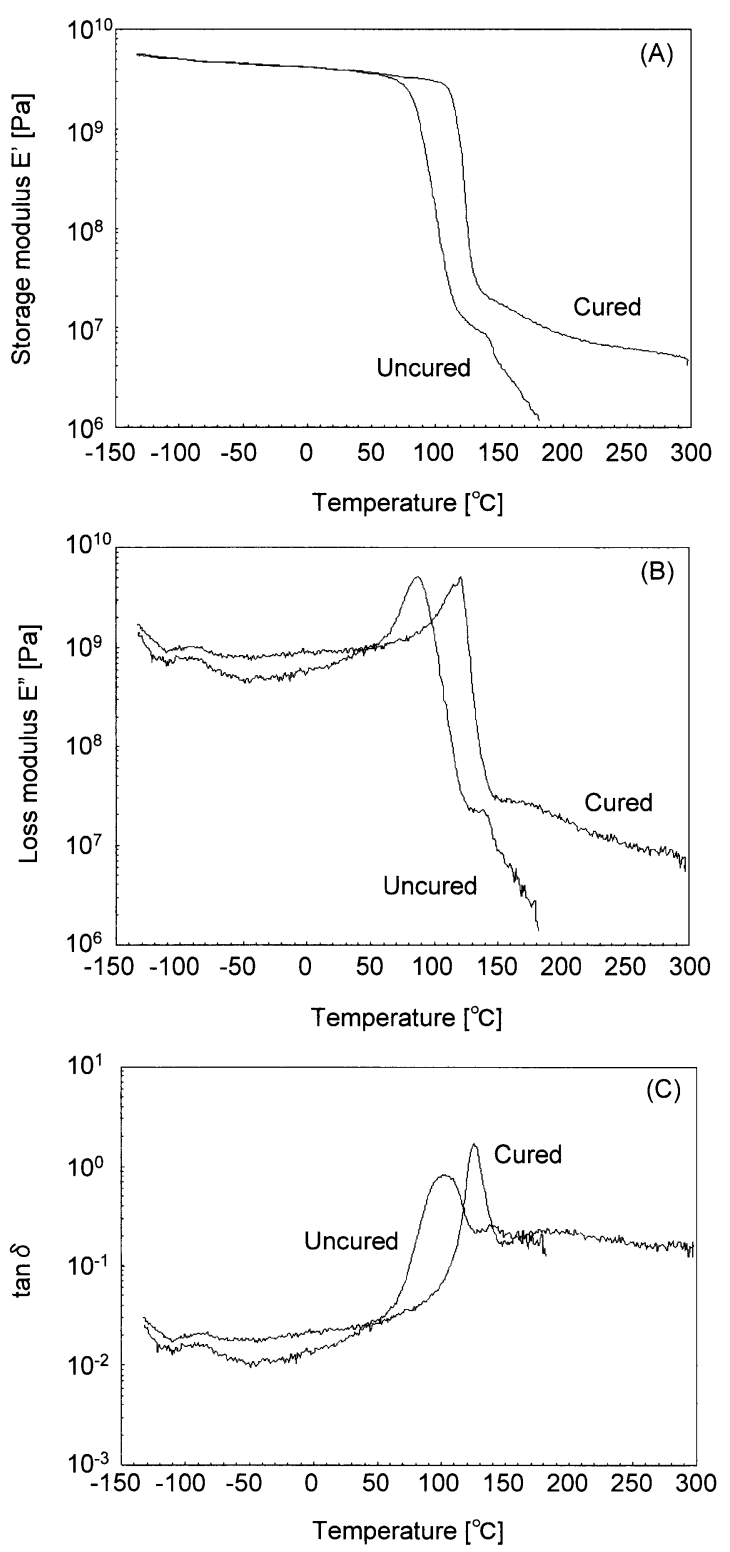

Fig. 5 Effect of curing on the dynamic mechanical properties of the composite film using PI-1

tween the uncured and cured films in the rubbery state region, while no difference was observed in the glassy state region (Fig. 5A). Because it is thermoplastic and has no network structure, the uncured film melted down over its $\mathrm{Tg}$. Moreover, because it has the network structure by the crosslinking of the epoxy resin component, the cured film was restrained from flowing even over its Tg.

The main peak temperatures of the loss modulus $\left(E^{\prime \prime}\right)$ and $\tan \delta$ of the uncured film were 87 and $103^{\circ} \mathrm{C}$, and those of the cured film were 121 and $126^{\circ} \mathrm{C}$ (Figs. $5 \mathrm{~B}$ and $5 \mathrm{C})$. These temperature rises are due to the effect of crosslinking of the epoxy resin component. On the other hand, the $E^{\prime \prime}$ peak of the cured film was slightly separated into two peaks, i.e., 115 and $121^{\circ} \mathrm{C}$ (Fig. 5B). Here, the $T g$ values of PI-1 and the fully cured epoxy resin were determined to be 120 and $97^{\circ} \mathrm{C}$ by DSC. Therefore, the separated $E^{\prime \prime}$ peak will be resulted from the phase separation of the base resin consisting of the polyimide and epoxy resin phases. The morphological structure of the base resin, which is the polyimide rich composition, would be the micro-phase separation structure consisting of the continuous phase of the polyimide component and the fine dispersed phase of the epoxy resin component. However, the separation of the $\tan \delta$ peak of the cured film was not observed (Fig. 5C). The compatible behavior of the cured base resin is probably not simple micro-phase separation but semi-IPN ${ }^{18)}$ between the linear polyimide and the epoxy resin network with some chemical reactions each other. The morphological behavior will affect to the reduced weight loss of the blend resin at over $400^{\circ} \mathrm{C}$ shown in Fig. 4A. In addition, it was observed that the $\tan \delta$ peak of the uncured film was broader than that of the cured film (Fig. 5C). The uncured film will cure gradually during measurement, resulting in the apparent $T g$ rise and broader $\tan \delta$ peak.

\subsection{Effect of Polyimide Structure on the Proper-} ties of the Composite Films

\subsubsection{Dynamic Mechanical Properties}

Dynamic mechanical behaviors of the cured composite films composed of the various polyimides (PI-1 to 6), the epoxy resin, and the silver filler were investigated (Fig. 6). The $E^{\prime}$ at $20^{\circ} \mathrm{C}$ of the film based on PI- 1 was $4.0 \mathrm{GPa}$, and those of the films based on PI-2, 3, 4, 5, and 6 were $3.5,2.8,3.9,2.8$, and $0.8 \mathrm{GPa}$, respectively (Fig. 6A). This difference in $E^{\prime}$ depends on the chemical structure of the polyimide as used. In particular, the $E^{\prime}$ of the film based on PI-6 was the lowest among the films, resulting from the flexible polysiloxane linkage having a rubbery state even at $20^{\circ} \mathrm{C}$. On the other hand, the $E^{\prime}$ at $250^{\circ} \mathrm{C}$ of the films based on PI-2 to 6 were similar (ranging from 2 to $3 \mathrm{MPa}$ ) irrespective of the polyimide as used. They were lower than that of the film based on PI-1 (6 MPa). The crosslinking of the epoxy resin component will restrict the flow of the films at the temperatures over their Tgs in spite of the decreased $T g$ of the polyimide as used.

The main peak temperatures of the $E^{\prime \prime}$ and $\tan \delta$ of the film lowered with decreasing $T g$ of the polyimide (Figs. $6 \mathrm{~B}$ and $6 \mathrm{C})$. The $\tan \delta$ peak temperature of the film closely depended on the $T g$ of the polyimide.

In the films based on PI-2 to 5 as well as PI-1, slightly separated peaks of $E^{\prime \prime}$ indicating the phase separation of the base resin were observed (Fig. 6B). In these shoulder- 

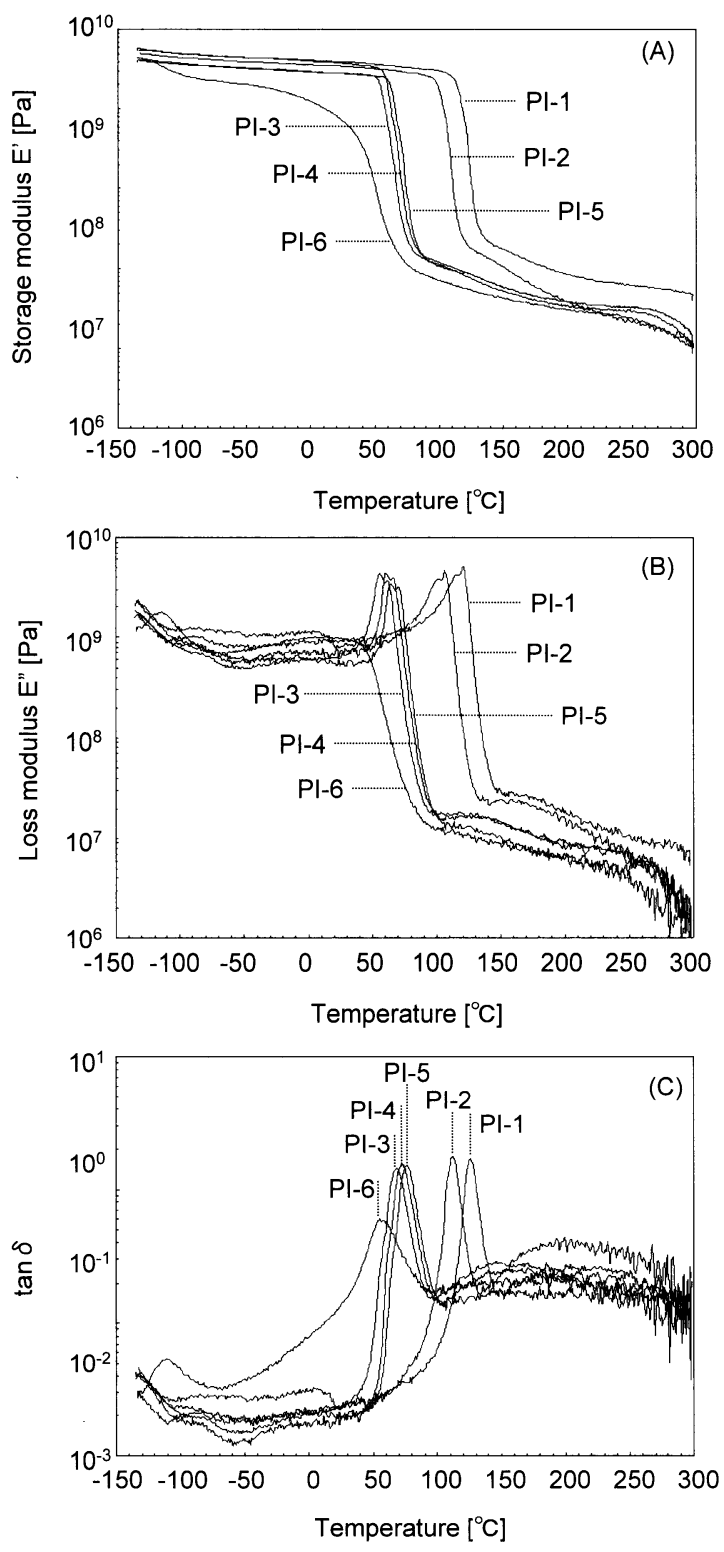

Fig. 6 Dependence of the dynamic mechanical properties of the composite films on polyimide structure

like shape $E^{\prime \prime}$ peaks, the higher peak is related to the $T g$ of the polyimide phase; the lower peak due to the $T g$ $\left(97^{\circ} \mathrm{C}\right)$ of the epoxy resin phase has shifted near to the $\mathrm{Tg}$ of the polyimide phase. These behaviors suggest that the epoxy resin phase is partially compatible with the polyimide phase.

On the other hand, the peak behaviors of $E^{\prime \prime}$ and $\tan \delta$ in the film based on PI- 6 were different from those of the other films (Figs. 6B and 6C). The $E^{\prime \prime}$ peak related to the $\mathrm{Tg}$ of PI- $6\left(30^{\circ} \mathrm{C}\right)$ was not clearly observed. The $\tan \delta$ peak of the film was observed at about $55^{\circ} \mathrm{C}$. However, the peak was broader and its intensity was lower than those of the other films. In addition, for the film based on PI-6, both the small peaks of the $E^{\prime \prime}$ and $\tan \delta$ were observed at about $-110^{\circ} \mathrm{C}$, which is the transition tempera- ture related to the siloxane units in PI-6 $6^{5)}$. This phenomenon suggests the existence of the phase separation between the polysiloxane unit and the other units in PI-6. The heterogeneity of this polyimide results in broadening the transition region to hide the $E^{\prime \prime}$ peak separation observed for the other films. Such peaks of the $E^{\prime \prime}$ and $\tan \delta$ were not observed for the film based on PI- 5 in spite of siloxane units. This result suggests that the compatibility between the siloxane units and the other units in the polyimide will improve with shortening the length of the siloxane linkages. The length of the siloxane linkages will affect the cohesion behavior of the polymer chains in the polyimide, resulting in further affecting the dynamic mechanical behavior of the film.

\subsubsection{Stress Relaxation Property}

Two materials having different coefficient of thermal expansion (CTE) are attached with an adhesive material by heat-pressing to yield thermal stress at the interface. If the adhesive material cannot relax the thermal stress, an internal stress will remain at the interface to yield a residual strain. When using a silicon chip (Si) and a copper substrate $(\mathrm{Cu})$ as the adherents having different CTE (3.5 and $17.0 \mathrm{ppm} /{ }^{\circ} \mathrm{C}$, respectively), a warpage of the silicon chip is caused as the result of the residual stress or the resultant strain (Fig. 3A). Here, the maximum thermal stress $\sigma_{\max }$ at the die corners was determined by the following equation ${ }^{19)}$ :

$$
\sigma_{\max }=K \cdot \Delta \alpha \cdot \Delta T \cdot(E a \cdot E s \cdot L / d)^{1 / 2}
$$

where $K$ is the geometric constant, $\Delta \alpha$ the difference in the CTE, $\Delta T$ the difference between the $T g$ of the adhesive material and room temperature, $E a$ and $E s$ the elastic moduli of respective adhesive material and copper substrate at room temperature, $L$ the side length of the silicon chip, and $d$ the thickness of the adhesive material. $T g$ and $E a$ are the two main factors to affect the thermal stress for the adhesive material.

With reference to the above theoretical interpretation, the stress relaxation properties of the composite films used as the adhesive materials were investigated. Fig. 7 shows the silicon chip warpage as a function of the storage modulus $E^{\prime}$ at $20^{\circ} \mathrm{C}$ and the $\tan \delta$ peak temperature (regarded as the $\mathrm{Tg}$ ) of the composite film. The warpage decreased (the stress relaxation property of the composite film improved) with decreasing $E^{\prime}$ and $\tan \delta$ peak temperature. In particular, the film based on PI- 6 was the most effective in relaxing the stress among the films examined. The correlation coefficient value between the 
(A)

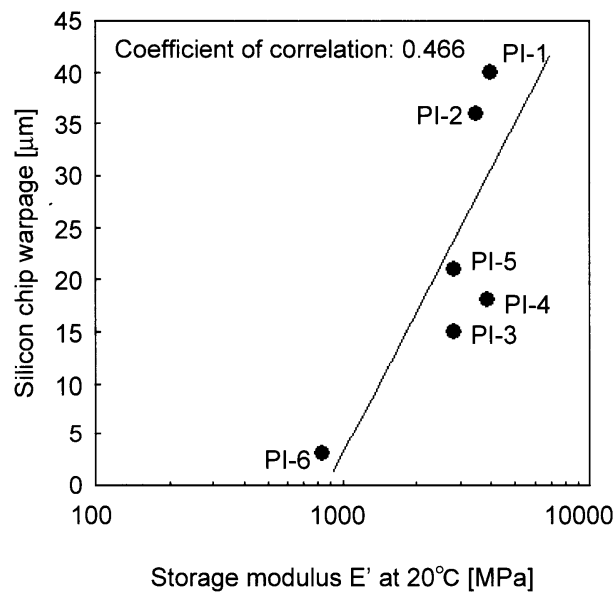

(B)

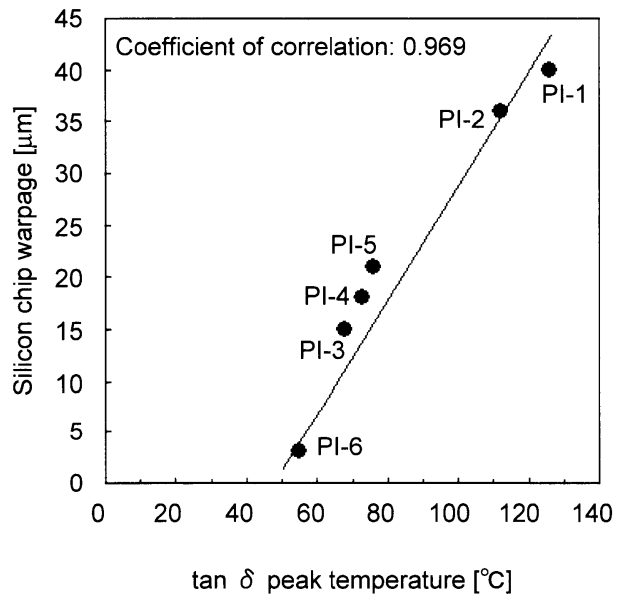

Fig. 7 Relationship between the storage modulus (A), $\tan \delta$ peak temperature (B) of the composite film and the silicon chip warpage

chip warpage and the $E^{\prime}$ was 0.466 (Fig. 7A), whereas that between the warpage and the $\tan \delta$ peak temperature was 0.969 (Fig. 7B). Therefore, the influence of the $\mathrm{Tg}$ on the warpage is more remarkable than that of the $E^{\prime}$. The difference in the thermal strain between the silicon chip and copper substrate during cool down after the die attachment is partly released by the movement of the film. This result indicates that lowering the $T g$, rather than the $E^{\prime}$ of the adhesive film, is more effective in stress relaxation and in decreasing residual strain.

\subsubsection{Adhesion Property}

The adhesion strengths of the composite films at $250^{\circ} \mathrm{C}$ are summarized in Table 3 . The failure modes were all cohesive failure of the film itself. The adhesion strength showed different behavior between the two groups of the specimens. Good correlation between the adhesion strength and the storage modulus $E^{\prime}$ at $250^{\circ} \mathrm{C}$ was observed for $\mathrm{Si} / \mathrm{Si}$ specimens: the adhesion strength tended to increase with increasing $E^{\prime}$. However, such correlation was not observed for the $\mathrm{Si} / \mathrm{Cu}$ specimens. The difference in adhesion behavior could be explained by the difference in the warpage. That is, while the $E^{\prime}$ of the film mainly affects the adhesion strength of the $\mathrm{Si} / \mathrm{Si}$ specimens because there is little or no warpage caused by the thermal stress, the stress relaxation property of the film additionally affects the adhesion strength of the $\mathrm{Si} / \mathrm{Cu}$ specimens because there will exist a thermal stress and the resultant warpage. For the films based on PI-1 and 2, the adhesion strength of the $\mathrm{Si} / \mathrm{Cu}$ specimen was remarkably low compared with that of the $\mathrm{Si} / \mathrm{Si}$ specimen, because the silicon chip warpage was far larger for the former than the latter. On the other hand, for the film based on PI-6, the adhesion strength of the $\mathrm{Si} / \mathrm{Cu}$ specimen was almost similar to that of the $\mathrm{Si} / \mathrm{Si}$ specimen, because the silicon chip warpage for both specimens was far smaller. Thus, the $E^{\prime}$ and the stress relaxation property of the adhesive film would be the two main factors to affect the adhesion strength in the case of specimens attaching two adherents having different CTE.

\section{Conclusions}

The polyimides synthesized from DBTA or DDBTA as a dianhydride and BAPP, TODE, DODE, TSX or PSX as a diamine had the Mn ranging from 23000 to 36000, the

Table 3. Adhesion property of the composite films ${ }^{\text {a) }}$

\begin{tabular}{|c|c|c|c|c|c|}
\hline \multirow{2}{*}{ Polyimide used in the film } & \multicolumn{2}{|c|}{ Adhesion strength at $250^{\circ} \mathrm{C}[\mathrm{MPa}]$} & \multirow{2}{*}{$\begin{array}{c}E^{\prime} \text { at } 250^{\circ} \mathrm{C} \\
{[\mathrm{MPa}]}\end{array}$} & \multicolumn{2}{|c|}{ Silicon chip warpage $[\mu \mathrm{m}]$} \\
\hline & $\mathrm{Si} / \mathrm{Si}^{\mathrm{b})}$ & $\mathrm{Si} / \mathrm{Cu}^{\mathrm{c})}$ & & $\mathrm{Si} / \mathrm{Si}^{\mathrm{b})}$ & $\mathrm{Si} / \mathrm{Cu}^{\mathrm{c})}$ \\
\hline PI-1 & 0.84 & 0.53 & 6.1 & 1 & 40 \\
\hline PI-2 & 0.43 & 0.26 & 2.2 & 1 & 36 \\
\hline PI-3 & 0.51 & 0.47 & 3.0 & 0 & 15 \\
\hline PI-4 & 0.58 & 0.51 & 3.3 & 0 & 18 \\
\hline PI-6 & 0.50 & 0.49 & 2.4 & 0 & 3 \\
\hline
\end{tabular}


Mw from 68000 to 121000 , the $T g$ from 30 to $120^{\circ} \mathrm{C}$. They showed excellent solubilitiy in NMP, DMAc, CHN, and THF, and low water absorptivity below $0.3 \mathrm{wt} \%$. The composite films composed of the polyimides, an epoxy resin and a silver filler showed thermoplastic behavior before curing with molten performance above their Tgs, and thermosetting behavior after curing with restrict flow behavior above their Tgs. The limited flow behavior is resulted from the network structure formation in the film due to the crosslinking of the epoxy resin component. Furthermore, it was found that the adhesion strength of the specimen composed of two solid adherents having different CTE and interfacial adhesive film was affected by the modulus and the stress relaxation property of the film. The stress relaxation property of the film will improve with decreasing the $T g$ of the polyimide.

（2004.8.25-受理）

\section{References}

1) A. K. S. Clair and T. L. S. Clair: "Addition Polyimide Adhesives Containing Various End Groups", Polym. Eng. Sci., Vol. 22, No. 1, pp. 9-14, 1982

2) D. Makino: "Recent Progress of the Application of Polyimides to Microelectronics", pp. 380-402, Polymers for Microelectronics, Kodansha, 1994

3) D. Wilson: "Recent Advances in Polyimide Composites", High Perform. Polym., Vol. 5, pp. 77-95, 1993

4) F. W. Harris and M. W. Beltz: "A New Readily Processable Polyimide", SAMPE J., Vol. 23, pp. 6-9, 1987

5) N. Furukawa, Y. Yamada and Y. Kimura: "Preparation and Stress Relaxation Properties of Thermoplastic Polysiloxane-Block-Polyimides", High Perfom. Polym., Vol. 8, pp. 617-630, 1996

6) J. L. Hedrick, H. R. Brown, W. Volksen and M. Sanchez: "Low-Stress Polyimide Block Copolymers", Polymer, Vol. 38, No. 3, pp. 605-613, 1997

7) L. Li and D. D. L. Chung: “Electrically Conducting Powder Filled Polyimidesiloxane", Composites, Vol. 22, No. 3, pp.
211-218, 1991

8) Y. Nakamura: "Particle-Dispersed Polymer Composite", J. Adhes. Soc. Jpn., Vol. 38, No. 11, pp. 442-447, 2002

9) K. Gaw, M. Kikei, M. Kakimoto and Y. Imai: "Preparation of Polyimide-Epoxy Composites", React. Funct. Polym., Vol. 30, pp. 85-91, 1996

10) C. C. Su and E. M. Woo: "Cure Kinetics and Morphology of Amine-Cured Tetraglycidyl-4,4'-diaminodiphenylmethane Epoxy Blends with Poly(ether imide)", Polymer, Vol. 36, No. 15, pp. 2883-2894, 1995

11) M. Kimoto: "Studies on Morphological Control and Mechanical Properties of Epoxy Composites", J. Adhes. Soc. Jpn., Vol. 36, No. 11, pp. 456-463, 2000

12) T. Masuko and S. Takeda: "Adhesion Behavior of Composite Films Composed of Polyimide, Epoxy Resin and Silver Filler", J. Adhes. Soc. Jpn., Vol. 40, No. 4, pp. 136-145, 2004

13) T. Masuko and S. Takeda: "Thermal and Mechanical Properties of Composite Films Composed of Polyimide, Epoxy Resin and Silver Filler", J. Network Polym. Jpn., Vol. 25, No. 4, pp. 181-192, 2004

14) B. N. Achar, G. M. Fohlen and J. A. Parker: "Synthesis and Characterization of Pure Bisphthalic Anhydrides Useful to Prepare Polymers with Ester-Imide Linkages", J. Polym. Mater., Vol. 2, pp. 64-68, 1985

15) S. H. Hsiao and P. C. Huang: "Synthesis and Characterization of Polyimides Based on Isopropylidene-Containing Bis(ether anhydride)s", J. Polym. Res., Vol. 4, No. 3, pp. 183-190, 1997

16) R. F. Fedors: "A Method for Estimating Both the Solubility Parameters and Molar Volumes of Liquids", Polym. Eng. Sci., Vol. 14, No. 2, pp. 147-154, 1974

17) T. Okitsu: "Development of Solubility Theory", Secchaku, Vol. 40, No. 8, pp. 342-350, 1996

18) S. Akiyama: "The Morphological Structures and Physical Properties of IPN and It's Prossibility to High Moduli", J. Network Polym. Jpn., Vol. 9, No. 4, pp. 216-227, 1988

19) J. C. Bolger: "Polyimide Adhesives to Reduce Thermal Stress in LSI Ceramic Packages", $14^{\text {th }}$ National SAMPE Tech. Conf., October, pp. 257-266, 1982 